\title{
Florida Crop/Pest Management Profile: Specialty Brassicas (Arrugula, Bok Choy, Chinese Broccoli, Chinese Mustard, Napa) 1
}

Mark A. Mossler²

\section{Production Facts}

- Over 4,500 acres of Chinese vegetables are being grown in Florida. Leafy brassica crops comprise a substantial amount of this acreage (1).

- Most leafy brassica production occurs in approximately six central and southern counties (1).

- Total acreage has remained steady over the past decade, with most of the produce exported to cities that have large Asian communities (1).

- Prices for Chinese leafy brassicas range from six to twelve dollars per crate, with a range of 300 to 500 crates per acre; equating to a value of $\$ 1,800$ - $\$ 6,000$ per acre (1).

\section{Production Regions}

Most leafy brassica production occurs in Miami-Dade, Palm Beach, Hillsborough, Manatee, Orange, and Seminole County. Approximately 3,100 acres of Chinese vegetables are grown in Palm Beach (2,800 acres on sand soil and 300 acres on muck soil). Planting begins in early to mid-September and continues until late April. Harvesting begins in late October and continues to late May. Most of the leafy brassicas grow best during cooler weather. Crops grown in warmer weather and when heavy rains are common are more subject to disease and insect pests as well as several physiological disorders (1).

\section{Production Practices}

Leafy brassicas are cultivated on raised beds ranging from 30 to 44 inches wide. The beds are pressed and the soil surface is often prepared with a cage cultivator to scarify the soil surface.

1. This document is PI-70, one of a series of publications of the Pesticide Information Office, Agronomy Department, Florida Cooperative Extension Service, Institute of Food and Agricultural Sciences, University of Florida. For additional Information, contact the Pesticide Information Office, University of Florida, P. O. Box 110710, Gainesville, Fl 32611-0710, (352) 392-4721. Published November 2005. Please visit the EDIS Web site at http://edis.ifas.ufl.edu.

2. Mark A. Mossler, Doctor of Plant Medicine, Pesticide Information Office, Agronomy Department. Florida Cooperative Extension Service, Institute of Food and Agricultural Sciences, University of Florida, Gainesville, FL 32611-0710.

The use of chemical names in this publication is solely for the purpose of providing specific information and does not constitute a recommendation. UF/IFAS does not guarantee or warranty the products named, and references to them in this publication does not signify our approval to the exclusion of other products of suitable composition. All chemicals should be used in accordance with directions on the manufacturer's label.

The Institute of Food and Agricultural Sciences (IFAS) is an Equal Opportunity Institution authorized to provide research, educational information and other services only to individuals and institutions that function with non-discrimination with respect to race, creed, color, religion, age, disability, sex, sexual orientation, marital status, national origin, political opinions or affiliations. U.S. Department of Agriculture, Cooperative Extension Service, University of Florida, IFAS, Florida A. \& M. University Cooperative Extension Program, and Boards of County Commissioners Cooperating. Larry Arrington, Dean 
Cross-ditches are often used to facilitate drainage. Most irrigation is by seepage, rather than overhead or drip. Most brassicas are short-season crops with maturities from seed ranging from 55 to 85 days; but these times can be shortened by using transplants. With between row distance of 11 or 14 inches and between plant distance of three inches to 18 inches, plant densities can range from 14,500 (bok choy, Chinese mustard) to over 110,000 plants per acre (Chinese broccoli). The plants are often cultivated two or three times and fertilized four or five times during production $(1,2)$.

The suggested variety of bok choy is Joi Choy, while China Pride and China Express are napa varieties. Green Lance is the suggested variety for Chinese broccoli (1).

\section{Worker Activities}

The vast majority of leafy brassicas are directly seeded by machine. If the season is short or conditions extremely weedy, transplants may be set. Workers setting transplants (approximately five days for a forty-acre farm) often wear latex gloves. A single worker is capable of thinning/hand weeding an acre a day. The only remaining labor includes harvest. Most brassicas are picked once, but Chinese broccoli and mustard may be picked two or three times. Plants are hand-cut by workers wearing gloves who pack approximately three acres a day $(1,2)$.

\section{Pest Management}

Since leafy brassicas are vegetative crops, the most important pest groups in Florida production include the early season diseases, weeds, and leaf-feeding insects. Mites, viruses, and nematodes are generally not problematic in Florida leafy brassica production.

\section{Insect/Mite Management}

\section{Insect/Mite Pests}

The principal insect pest group on leafy brassicas in Florida is lepidoptera larvae (caterpillars). These include diamondback moth, cutworms (granulate, black), armyworms (beet, fall, and southern), cross-striped cabbage worm, and cabbage looper. Although generally not plant damaging, the physical presence of aphids results in downgrading of the crop. Occasional or minor arthropod pests include leafminers and the yellowmargined leaf beetle. Fire ants sometimes disrupt harvest, or become predators of the plants for lack of any other vegetation $(2,3)$.

Diamondback Moth (Plutella xylostella). Diamondback moth is a small moth with long antennae. It is grayish-brown with a broad cream or light brown band along the back. The band can have constrictions, which give it a diamond-like pattern. The wing tips also turn up at the ends. Female moths attach eggs singly or in groups of two or three to the underside of leaves. All four larval stages are small and larvae wriggle violently if disturbed and will drop from the leaf suspended by a strand of silk. The larvae are green in all but the first instar, in which they are colorless. Larvae can feed for ten days to a month, depending on temperature. Pupation in a loose transparent cocoon may take three to four days. In southern Florida, diamondback moth is most abundant from December to February or March, but is rare after the end of May (3).

Diamondback moth can attack plants at all stages of growth. Larvae chew small holes in leaves, with larger larvae making larger holes. They may make leaves appear "windowpaned", with a clear cuticle remaining after feeding. They also attack developing heads. The resulting damage deforms the heads and provides entry points for decay pathogens. There are a number of natural predators of diamondback moth in Florida. Collard trap crops are often planted around field perimeters, and growing during the warm months is discouraged so that resistant individuals die out (3). For diamondback moth and armyworms, growers also try to use "softer" insecticides such as B.t., spinosad, emamectin, and neem to avoid intensifying leafminer pressure. There is also rotation within the B.t.s (rotating aizawai and kurstaki strains). Permethrin is generally avoided because its use may actually increase moth populations by killing natural enemies (1).

Cutworms [granulate cutworm, (Feltia subterranea), black cutworm (Agrotis ipsilon)]. Cutworms are stout caterpillars with a dull, greasy 
appearance. Cutworms cleave seedlings off at or just below the soil line. They may also damage leaves. Black cutworms do most of their feeding at ground level; the larvae feeding on young plants and cutting off leaves, or in later instars, entire plants.

Populations tend to be higher in weedy or wet fields. Granulate cutworm larvae can cut off entire seedling plants, as well as climb and feed on leaves of older plants. This cutworm is not associated with weedy fields as is the black cutworm. First instar larvae remain on the plants, while older larvae climb and feed on plants only during the night. In some areas, natural enemies of cutworms exert control pressure that may approach 80 percent. However, seedlings emerging in fields without this protection can experience substantial stand loss (3).

Beet Armyworm (Spodoptera exigua). Beet armyworm is a slender striped larvae that feeds on leaves. The moth is capable of laying over 600 eggs, in masses of 100, on the underside of plant leaves, which are covered with fuzzy white scales. Larvae emerge from egg masses in three to four days. They feed in groups during the first instar and then disperse on the wind using silken threads. Larvae enter the soil to pupate after one to three weeks of feeding. Adults emerge in 7 to 10 days. Consequently, generations can be spawned monthly (3).

\section{Southern Armyworm (Spodoptera eridania).}

As with beet armyworm, larvae emerge from egg masses in three to four days. They feed in groups during the first instar and then disperse on the wind. Larvae feed on the older leaves and move down into the crowns and heads near the base of the plants. Larvae enter the soil to pupate after two to three weeks of feeding. Adults emerge in 7 to 8 days, creating one life cycle in less than a month in some cases. It has also been noted that the insecticide spinosad is no longer controlling this caterpillar at historically-used rates (4).

\section{Fall Armyworm (Spodoptera frugiperda).} Adults can be seen along the north Florida coast during all months but are most abundant from April to December. The fall armyworm does not enter diapause and cannot survive extended periods of low temperatures, instead maintaining populations in warmer areas from which adults move northward in the spring. Eggs are laid in masses of 100 to 150, and each moth may lay over a thousand eggs in total. Control at the egg stage is extremely difficult, due to the protective covering over the mass and its position on the underside of leaves. Larvae typically damage plants by leaf and petiole feeding. Although the life cycle of the fall armyworm can be completed in about 30 days during the summer, it can take 60 days in the spring and fall and up to 90 days during the winter $(5,6)$.

\section{Cross-Striped Cabbageworm (Evergestis} rimosalis). Adults are about one inch in size, straw-colored, and marked with olive or purplish-brown. Eggs are laid in small masses and they are oval, flattened, and overlapping. The larvae are gray with black tubercles which then become bluish-gray with numerous transverse black bands. The larvae feed on leaves and can burrow to the center of the plants crown if uncontrolled. The moth is active during the cool season, where it can take up to two months to reproduce, but this cycle may be as short as 18 days in warm weather (3).

Cabbage Looper (Trichoplusia ni). Another leaf-feeding caterpillar is the cabbage looper, which is green with white stripes along the body. Moths deposit eggs singly or in small groups of up to seven. Females can produce 300 to 600 eggs in their two-week life span. Larvae emerge from eggs in 3 to 4 days and feed on leaves. Larvae develop for two to four weeks, and then spin cocoons on the host plant for pupation. Adults emerge in five to ten days and the entire cycle can take as little as 18 days (3).

Aphids [green peach aphid (Myzus persicae), turnip aphid (Lipaphis erysimi), and cabbage aphid (Brevicoryne brassicae, among others]. Aphids feed by piercing plant tissue with their needle-like mouthparts (stylets), sucking out water and nutrients from the vascular system of the plant. Feeding damage and toxins in the saliva result in thickening, crumpling, and downward curling of leaves. Heavy aphid attack may kill very young plants. Aphids also deposit honeydew on the plant surface, which encourages the growth of sooty mold. A short life cycle and asexual reproduction by live birth allows aphid populations to increase rapidly in Florida (3). Imidacloprid is often used at seeding and possibly 
once more during the season to manage these insects (1).

\section{Leafminers (Liriomyza sativae and Liriomyza} trifolii). The adult fly punctures the upper leaf surface while feeding, and the female inserts eggs into the puncture holes. When each larva (maggot) emerges, it feeds between the upper and lower leaf surfaces, creating a tunnel or mine that winds across the leaf and becomes larger as the maggot grows. When larval development is complete, the maggot cuts through the leaf surface and emerges from its mine, dropping to the soil to pupate. Leafminer populations can increase rapidly in Florida, where the life cycle may be as short as 21 to 28 days. Leafminers can often be controlled with several applications of cyromazine and severe outbreaks can be avoided by limiting the use of non-selective insecticides $(1,6)$.

\section{Yellowmargined Leaf Beetle (Microtheca} ochroloma). Although the biology of this beetle is not well understood, it is confined to the Gulf Coast areas and only feeds on brassicas. Eggs are bright orange and elongate and are deposited singly or in small clusters in protected spots on the plant or in leaf litter. It may take up to a month to develop into an adult. The small black beetles are active all winter and feed in protected spots for up to three months (3).

\section{Chemical Control}

Based on a 2004 UF survey, Florida growers applied insecticides on 100 percent of the state's leafy brassica acreage. There was reported use of B.t., emamectin, indoxacarb (napa, Chinese broccoli, Chinese mustard only), methomyl (napa only) and spinosad (2). Other insecticides registered for leafy brassicas in Florida in 2005 were acetamiprid, azadirachtin, bifenthrin (napa, Chinese broccoli, Chinese mustard only), carbaryl (napa, bok choy, and Chinese mustard only), chlorpyrifos (napa, bok choy, Chinese broccoli, only), cyfluthrin (napa, Chinese broccoli, Chinese mustard only), cypermethrin, diazinon (all but arrugula), cyromazine, dinotefuran, disulfoton (napa only), esfenvalerate (napa and Chinese broccoli only), imidacloprid, kaolin, lambda-cyhalothrin (napa, Chinese broccoli, Chinese mustard only), malathion, methoxyfenozide, naled (napa only), oils, oxydemeton (napa only), permethrin (all but bok choy), pymetrozine, pyrethrins +/- rotenone, pyriproxyfen (all but arrugula), spiromesifen, tebufenozide, thiodicarb (arrugula only), and zeta-cypermethrin (all but arrugula). Methoprene, spinosad, and pyriproxyfen are available for fire ant control (1).

Spinosad (Spintor®). Spinosad is a microbial fermentation product that is toxic to select insects, and as such, has negligible effects on populations of certain beneficial arthropods. Growers use it to manage mainly lepidopteran larvae and leafminers. The price of spinosad is $\$ 262.50$ per pound of active ingredient (ai), and the approximate cost of a maximum labeled application $(0.156 \mathrm{lb}$ ai/A) is $\$ 40.96(7,8)$. Spinosad may be applied up to one day before harvest $(\mathrm{PHI}=1$ day), and the restricted entry interval (REI) under the Worker Protection Standard is 4 hours. The label states that other chemistries should be used after three consecutive spinosad applications and there is a $0.45 \mathrm{lb}$ ai/A limit per crop.

Emamectin (Proclaim ${ }^{\circledR}$ ). Emamectin is a soil bacterium derivative compound that is used to manage lepidopteran pests. The price of emamectin is $\$ 2,462$ per pound of active ingredient, and the approximate cost of a maximum labeled application $(0.015 \mathrm{lb}$ ai/A) is $\$ 37.25(7,9)$. The label states that seven days should be allowed between applications and no more $0.091 \mathrm{lb}$ ai/A can be applied to any one crop. The REI is 48 hours and the PHI is 14 days.

Indoxacarb (Avaunt $\left.{ }^{\circledR}\right)$. Indoxcarb is an oxadiazine insecticide that affects caterpillars; while affecting other insects to a much lesser degree. The price of indoxacarb is $\$ 262$ per pound of active ingredient, and the approximate cost of a maximum labeled application (0.065 lb ai/A) is $\$ 17.03(7,10)$. The label states that three days should be allowed between applications and no more $0.26 \mathrm{lb}$ ai/A can be applied to any one crop. The REI is 12 hours and the $\mathrm{PHI}$ is 3 days.

Methomyl (Lannate $\left.{ }^{2}\right)$. Methomyl is a broad-spectrum carbamate insecticide used to manage caterpillars and beetles. The median price of methomyl is $\$ 25.12$ per pound of active ingredient and the approximate cost per maximum labeled application $(0.9 \mathrm{lb}$ ai/ $/ \mathrm{A})$ is $\$ 22.61$ per acre $(7,10)$. Methomyl may be applied up to 10 days prior to 
harvest ( $\mathrm{PHI}=10$ days), and the REI is 48 hours. No more than 10 applications may be made to the crop and the material limit is $7.2 \mathrm{lb}$ ai/acre/crop.

\section{Alternative Chemicals}

Over the past few years, there have been a number of new "reduced risk" materials registered for use on some or all of the leaf brassicas.

Pymetrozine, dinotefuran, and spiromesifen are good examples of this trend. These materials are generally more selective than those of historic use. These materials are currently being assessed for fit into established IPM systems.

\section{Cultural Control}

Scouting is the number one cultural practice employed by growers, and all responded that production areas were scouted regularly. Growers also reported using mulches, removing field and perimeter vegetation, and plowing in residue as measures to clean up refugia and reduce local pest populations such as southern armyworm and cutworms. They also reported altering planting date and rotating pesticides and crops.

\section{Biological Control}

There is a measure of natural parasitism for most all crop pests in Florida. However, control of the pests does not occur at a rate that will preclude economic damage. Most growers go "soft" on early season insect management to encourage spider predation of aphids and other predatory interactions.

\section{Disease Management}

\section{Disease Pathogens}

Diseases are generally a minor problem in any given year. The most important diseases of leafy brassicas are downy mildew (caused by Peronospora parasitica), cercospora and alternaria leafspot, bacterial leafspot and rot, and anthracnose (caused by Colletotrichum higginsianum). Other minor diseases include damping-off (caused by Rhizoctonia spp., and Pythium spp.) and sclerotinose (caused by Sclerotinia sclerotiorum $)(2,11)$.
Downy Mildew (Peronospora parasitica). Although generally observed on leaf tissue, downy mildew can grow on flowers and stems as well. Black or dark specks appear on young leaves first, usually on the underside. Spots are often irregular and net-like. The upper part of the leaf will also develop dark spots similar in shape and may be accompanied by yellowing. As the lesions mature, the spots can coalesce, resulting in larger areas of sunken, tan-colored spots. White fungal growth is observed during times of wetness on the lesions. Downy mildew infection predisposes plants to bacterial soft rot or sclerotinose (11).

Fungal Leaf Spots (Cercospora spp. and Alternaria spp.). Cercospora leaf spot is generally a fall disease due to the warm weather. It appears as distinct spots, which are circular to angular, pale-green to light-brown. A yellow halo is often associated with the lesion.

Alternaria leaf spot appears as small dark brown or black spots on the leaves. As the spots enlarge, zonation, or target spot, becomes evident. As spores are produced, the spot becomes darker in the middle. With the development of numerous spots, the leaves may turn yellow and die (11).

Bacterial Diseases (caused by Xanthomonas campestris pv. campestris and Pseudomonas cichorii). These two bacteria cause black rot and bacterial leaf spot, respectively. Black rot is first observed as areas of yellow and light brown with a network of black veins in the leaves. There are often $\mathrm{V}$-shaped areas at the edges of the leaves. Movement of the bacteria down the leaf veins into the vascular tissue of the stem produces the systemic stage of the disease, as the bacteria use the plants vasculature to colonize uninfected leaves.

Bacterial leaf spot begins as slightly sunken gray-brown to dark-brown round or oval spots up to about $6 \mathrm{~mm}$ in diameter, and may coalesce. Disease occurs mainly on the wrapper leaves, but may cause injury to inner leaves under favorable conditions (11).

Anthracnose (caused by Colletotrichum higginsianum). Anthracnose is observed particularly on napa. Small dry circular, gray to straw-colored 
leaf spots are produced. On leaf petioles and stalks the spots are sunken, elongated and gray to brown with black borders (11).

Damping-Off (caused by Rhizoctonia spp. and Pythium spp.). Damping-off is observed every year during warm wet weather periods. Less than five percent of acreage is affected by this, but it can approach 100 percent in some rare cases. Those seedlings which do emerge often show water-soaking around the stem, with a collapsed area near the soil line. Damping-off often is seen in circular areas or for some distance within the row (11).

\section{Sclerotinose (caused by Sclerotinia} sclerotiorum). Infection occurs on leaves and stems nearest the ground, or on the wrapper leaves in cabbage. A small water-soaked spot appears and as it enlarges, a growth of white mycelium is produced. As the fungus grows upward on a maturing plant, it often spreads over the crown or head, darkening the leaves into soft, water soaked masses. At this stage, numerous black sclerotia from 3 to $25 \mathrm{~mm}$ are produced on dead and dying plant parts. Sclerotinose often favors periods of plant stress, such as inclimate temperature or previous disease events (11).

\section{Chemical Control}

In 2004, Florida growers applied fungicides on a majority of the state's leafy brassica acreage. There was use of chlorothalonil (Chinese broccoli and napa only), fosetyl-Al, iprodione (Chinese mustard and broccoli only), maneb (napa and bok choy only), and mefenoxam (1). Other fungicides or disease-preventing products registered for use in leafy brassicas in Florida in 2005 were acibenzolar (all but arrugula), azoxystrobin, Bacillus subtilis, Bacillus pumilus, Coniothyrium minitans, cyprodinil + fludioxonil (all but arrugula and Chinese mustard), fludioxonil (seed treatment only), fosetyl-Al, mefenoxam, PCNB (Chinese broccoli and napa), potassium salts of fatty acids (all but arrugula and Chinese mustard), potassium bicarbonate, phosphoric acid solutions, pyraclostrobin, and sulfur.

Maneb. Maneb is an ethylenebis(dithiocarbamate) (EBDC) fungicide which is used prophylactically, primarily for the management of downy mildew and alternaria leaf spot (1). The median price of maneb is $\$ 4.00$ per pound of active ingredient, and the approximate cost per maximum labeled application (1.6 lb ai/A) was $\$ 6.40$ per acre $(7,12)$. Maneb may be applied up to ten days before harvest (PHI=10 days), and the REI under the Worker Protection Standard is 24 hours. No more than 9.6 pounds of active ingredient per acre may be applied during a season.

Chlorothalonil. (Bravo®). Chlorothalonil, a broad-spectrum nitrile fungicide, is used for the control of downy mildew, but also for alternaria leaf spot (1). The median price of chlorothalonil is $\$ 10.32$ per pound of active ingredient, and the cost per maximum labeled application (1.2 lb ai/A) was $\$ 12.38$ per acre $(7,9)$. The PHI and REI for chlorothalonil are 7 days and 12 hours, respectively. There is a material limit of $12 \mathrm{lb}$ ai/acre/season. The minimum re-treatment interval is seven days.

Iprodione. (Rovral®). Iprodione is a dicarboximide fungicide used for the control of alternaria leaf spot in Chinese mustard (1). The median price of iprodione is $\$ 40.00$ per pound of active ingredient, and the cost per maximum labeled application (0.5 lb ai/A) was $\$ 20.00$ per acre $(7,13)$. The PHI and REI for iprodione are 10 days and 24 hours, respectively. There is a limit of four applications per season.

Mefanoxam. (Ridomil Gold®). Mefenoxam is a systemic acylalanine fungicide used to manage damping off and downy mildew (1). It is applied pre-plant or at planting. The median price of mefenoxam is $\$ 157.00$ per pound of active ingredient, and the cost per maximum labeled application (1.0 lb ai/A) was $\$ 78.50$ per acre $(7,9)$. The REI for mefenoxam is 48 hours.

Fosetyl-Al. (Aliette $\left.{ }^{\circledR}\right)$. Fosetyl-aluminum (fosetyl-Al) is an aluminum ester of alkyl phosphonate used in the management of downy mildew (1). The median price of fosetyl-Al is $\$ 13.44$ per pound of active ingredient and the cost per maximum labeled application (4.0 lb ai/A) was $\$ 53.76$ per acre $(7,13)$. Restrictions include maximums of seven applications per season. The PHI 
and REI for fosetyl-Al are 3 days and 12 hours, respectively.

\section{Alternative Chemicals}

In addition to strobilurin fungicides such as azoxystrobin and pyraclostrobin, several other new fungicides have been registered for use in leafy brassicas. Acibenzolar (for viral and bacterial pathogens) and cyprodinil+ fludioxonil (for soil-borne pathogens) are materials that are just now being examined for overall utility in Florida production.

\section{Cultural Control}

Scouting is the number one cultural practice employed by specialty leafy brassica growers. Growers also reported using mulches, removing field and perimeter vegetation, and plowing in residue as measures to reduce inoculum reservoirs in the immediate vicinity. They also alter planting date and rotate pesticides and crops.

\section{Biological Control}

Several microbial pesticide products have been registered for use in specialty leafy brassica production. Two species of Bacillus spp. bacteria and the fungal hyperparasite Coniothyrium minitans are being investigated for the overall utility in disease management.

\section{Weed Management}

\section{Weed Pests}

Since specialty leafy brassicas are quick-growing, short season crops; weed competition in the early emergence period is a critical consideration. For example, one wild radish plant per meter of row will reduce yield significantly during the cooler part of the season. Most growers choose cultivation for weed control, which is conducted mechanically two or three times during the season $(2,14)$.

A variety of weeds are problematic for Florida producers, including nutsedges (yellow and purple), grasses such as goosegrass, and broadleaf weeds, such as pusley and purslane. Amaranths (livid, spiney, or common) are particularly troublesome (14).

Amaranth (Amaranthus spp.). Amaranths (pigweeds) are annual broadleaf herbs with erect stems that can grow to six feet tall. Several species of amaranth are present in brassica growing areas, including livid amaranth (Amaranthus lividus), smooth pigweed (Amaranthus hybridus), and spiny amaranth (Amaranthus spinosus). Amaranths reproduce solely by seed, producing very small, dark seeds. They prefer open areas with bright sunlight $(15,16)$.

Nutsedge (Cyperus spp.). Yellow nutsedge ( $C$. esculentus) and purple nutsedge (C. rotundus) are problems in Florida brassica production. Both of these perennial sedges are found in disturbed habitats throughout Florida and the southeast U.S. Yellow nutsedge may produce some seed but reproduces primarily by rhizomes and tubers. The parental plant develops rhizomes, which end in bulbs or tubers that produce new plants. Tuber production is favored by low nitrogen levels and high temperatures (80 to $91^{\circ} \mathrm{F}$, or 27 to $33^{\circ} \mathrm{C}$ ). The plant is tolerant of high soil moisture but is intolerant of shade. Purple nutsedge is also able to reproduce from tubers when conditions are harsh, making it difficult to control. Unlike the rhizomes of yellow nutsedge, purple nutsedge rhizomes growing off the parent plant produce new plants in a series ("tuber-chains"). The plant also reproduces by seed to a limited degree. Although purple nutsedge is also intolerant of shade, it is able to survive a wide range of environmental conditions, growing well in nearly all soil types and over a range of soil moisture, soil $\mathrm{pH}$, and elevation. Purple nutsedge is also able to survive extremely high temperatures (15).

Goosegrass (Eleusine indica). Goosegrass is similar in appearance to crabgrass, but grows more densely. It is also a summer annual, and it prefers sunny, moist conditions. Reproducing by seed, it flowers from July to October $(15,16)$.

Florida Pusley (Richardia scabra). Florida pusley is a loosely branched annual that stands erect or lies flat on the ground. Its hairy stems and oppositely arranged leaves are often rough in texture, 
particularly along the main veins. The plant is often mixed with Brazilian pusley ( $R$. brasiliensis). Florida pusley reproduces by seed and blooms in any month in the absence of frost (17).

Purslane (Portulaca oleracea). Purslane is a broadleaf summer annual with a single taproot from which arise multiple branched, purplish-red stems that often form large mats. Clusters of small leaves are found at the end of its branches. The plant reproduces by seed, flowering from August to October. Being resistant to drought, it is difficult to kill. However, it is susceptible to frost injury $(15,16,18)$.

\section{Chemical Control}

Herbicides registered for use in leafy brassicas in Florida in 2005 were bensulide, carfentrazone, clethodim, DCPA (all but arrugula), glyphosate, paraquat (napa only), sethoxydim, and s-metolachlor [only on napa by 24(c) registration]. Glyphosate, paraquat, and carfentrazone are contact herbicides, while the others are selective. Growers utilizing s-metolachlor use reduced rates, as this herbicide tends to carry over to some extent. Following label directions when applying herbicides is essential. Some of the preemergence herbicides rates are specific for mineral sands (bensulide, DCPA), while others will work better at slightly higher rates in muck soils (s-metolachlor).

Paraquat (Gramoxone ${ }^{\circledR}$ ). Paraquat is a non-selective bipyridilium herbicide used to manage many annual and perennial weeds. The median price of paraquat is $\$ 19.97$ per pound of active ingredient, and the approximate cost per labeled application (0.94 lb ai/A) was $\$ 18.77$ per acre $(7,9)$ when used prior to emergence, but only $\$ 9.99$ when used for row middle control with a shielded sprayer. Paraquat may be applied up to harvest and the REI is 24 hours.

Sethoxydim (Poast $\AA$ ). Sethoxydim is a cyclohexene, postemergence herbicide used to manage many annual and perennial grass weeds. It does not control sedges or broadleaf weeds. The median price of sethoxydim is $\$ 47.45$ per pound of active ingredient, and the approximate cost per maximum labeled application $(0.28 \mathrm{lb}$ ai/A) was $\$ 13.35$ per acre $(7,19)$. Sethoxydim may be applied up to 15 days before harvest for arrugula, but the PHI is 30 days for napa, bok choy, Chinese mustard, and Chinese broccoli. The REI is 12 hours. A maximum of 0.56 pounds of active ingredient over the season may be applied per acre.

\section{Alternative Chemicals}

One of the few new herbicides for leafy specialty brassicas is carfentrazone. Since these crops are often weeded mechanically, there are concomitantly less requests for IR-4 assistance.

\section{Cultural Control}

Some perennial weed management (mechanical, chemical, sometimes flooding) is done off-season if the land is not leased. However, there are few cultural weed management practices that support these specialty crops.

\section{Nematode Management}

Nematodes are microscopic roundworms living in the soil which feed on plant roots and damage the tissue. Specialty leafy brassica growers do not use fumigation as the crops are short-lived and land is often leased. Most soil sterilants are too expensive for growers to use. For those growers requiring nematode management, dichloropropene, fenamiphos (napa and bok choy only), and metam sodium are labeled for this use. Fermentation products from Myrothecium verrucaria (Ditera $\left.{ }^{\circledR}\right)$ are also labeled as nematicidal products.

\section{Key Contacts}

- Michael Aerts is the assistant director of the Environmental and Pest Management Division of Florida Fruit and Vegetable Association. He facilitates communication between commodity and regulatory agencies. Mr. Aerts can be reached at: FFVA, 800 Trafalgar Ct. Suite Maitland, FL 32794-8153, (321) 214-5200, maerts@ffva.com.

- Mark Mossler is a Doctor of Plant Medicine in the Pesticide Information Office at the University Floridas Institute of Food and Agricultural Sciences. He is responsible for providing information to the public and governmental agencies. Dr. Mossler can be reached at PIO, 
Box 110710, Gainesville, FL 32611, (352)

392-4721, mamossler@ifas.ufl.edu.

\section{References}

1. Olson, S.M. (2004). Guidelines for Chinese Leafy and Root Crop Vegetables in South Florida. Horticultural Sciences Department document HS741. Florida Cooperative Extension Service, Institute of Food and Agricultural Sciences, University of Florida. http://www.usda.gov/nass/pubs/ranking/ vrank97.htm

2. Personal communication with Phyllis Gilreath, Crop Production Specialist. University of Florida, Manatee County Cooperative Extensions Service, April, 2004.

3. Webb, S.E. (2004). Insect Management for Crucifers (Cole Crops) (Broccoli, Cabbage, Cauliflower, Collards, Kale, Mustard, Radishes, Turnips). Entomology \& Nematology Department document ENY-464. Florida Cooperative Extension Service, Institute of Food and Agricultural Sciences, University of Florida.

4. Personal communication with Gregg Nuessly, Crop Protection Specialist. University of Florida, Everglades Research and Education Center, Belle Glade. 2004.

5. Capinera, J.L. (1999). "Fall armyworm." UF/IFAS Featured Creatures. EENY-98. Available: http://www.ifas.ufl.edu/ insect/field/ fall_armyworm.htm

6. Johnson, F.A. and Stansly, P.A. (1999). Insects That Affect Vegetable Crops. Entomology and Nematology Department ENY 450. Florida Cooperative Extension Service, Institute of Food and Agricultural Sciences, University of Florida.

7. DPRA, 2001, or personal communication with Helena Chemicals, Alachua, FL, 2005.

8. Dow AgroSciences labels, Midland, MI.

9. Syngenta labels, Research Triangle Park, NC.
10. Dupont labels, Wilmington, DE.

11. Kucharek, T. (2004). 2004 Florida Plant Disease Management Guide: Crucifers. Department of Plant Pathology document PDMG-V3-37. Florida Cooperative Extension Service, Institute of Food and Agricultural Sciences, University of Florida.

12. Cerexagri labels, Philadelphia, PA.

13. Bayer CropScience labels, Research Triangle Park, NC.

14. Stall, W.M. (2003). Weed Control in Cole or Brassica Leafy Vegetables. Horticultural Sciences Department document HS189. Florida Cooperative Extension Service, University of Florida, Institute of Food and Agricultural Sciences.

15. Miller, J.F., Worsham, A.D., McCormick, L.L., Davis, D.E., Cofer, R. and Smith, J.A. (1975). Weeds of the Southern United States. Florida Cooperative Extension Service, Institute of Food and Agricultural Sciences, University of Florida. Gainesville, Florida.

16. Lorenzi, H.J. and Jeffery, L.S. (1987). Weeds of the United States and Their Control. Van Nostrand Reinhold Company, New York.

17. Stall, W.M. (2003). Weed Control in Cucurbit Crops (Muskmelon, Cucumber, Squash, and Watermelon). Horticultural Sciences Department document HS190. Florida Cooperative Extension Service, University of Florida, Institute of Food and Agricultural Sciences.

18. Stephens, J.M. (1994). Purslane - Portulaca oleracea L. Horticultural Sciences Department Fact Sheet HS-651, Florida Cooperative Extension Service, Institute of Food and Agricultural Sciences, University of Florida.

19. BASF labels, Research Triangle Park, NC. 